\title{
Substitution of Expensive Protein Sources by Soybean Meal Supplemented with a $\beta$-Mannanase Enzyme Results in Improved General Clinical Health Score during the Post-Weaning Period
}

\author{
Vangroenweghe Frédéric ${ }^{1,2, *}$ and Poulsen $\mathrm{Karl}^{3}$ \\ ${ }^{1}$ Elanco, BU Food Animals, Plantijn en Moretuslei 1A - 3rd floor, 2018 Antwerpen, Belgium \\ ${ }^{2}$ Ghent University, Faculty of Veterinary Medicine, Unit of Porcine Health Management, Merelbeke, Belgium \\ ${ }^{3}$ Elanco, BU Nutritional Health, Plantijn en Moretuslei 1A - 3rd floor, 2018 Antwerpen, Belgium
}

${ }^{*}$ Corresponding author: Frédéric Vangroenweghe, BU Food Animals, Elanco Benelux, Plantijn en Moretuslei 1A - 3rd floor, 2018 Antwerpen, Belgium; Tel: (+32)-3-334-30-00

Received: October 14, 2020; Accepted: October 20, 2020; Published: October 24, 2020

\begin{abstract}
Enzyme supplementation with a $\beta$-mannanase to degrade $\beta$-mannan fibers present in the diet has been to shown restore and improves performance in swine. The current study compared the effects of a commercial 2-phase piglet post-weaning diet (Control) and an adapted diet supplemented with a $\beta$-mannanase (Hemicell HT; Elanco) (Enzyme) on the performance of post-weaned piglets. The alternative diet with $\beta$-mannanase performed equal to the regular commercial formulation $(P>0.05)$ with no need for antimicrobial treatment during the entire trial period. No mortality occurred in any of both treatments. The general clinical condition scores were significantly $(P<0.05)$ better in the Enzyme-treated as compared to the Control group. Fecal clinical scores did not differ significantly $(P>0.05)$ among treatment groups. In conclusion, the current study suggests that the use of an exogenous heattolerant $\beta$-mannanase allowed reduced levels of expensive protein sources to be used in the first diet post-weaning, and an energy reduction of $63 \mathrm{kcal} /$ $\mathrm{kg}$ net energy to be used in the second diet without adverse effects on intestinal health or overall performance. In fact, the general clinical condition was scored significantly $(P<0.05)$ better on the $\beta$-mannanase supplemented diets.
\end{abstract}

Keywords: $\beta$-Mannanase, Protein substitution, Weaned piglets, Performance

\section{Introduction}

Piglet post-weaning diets are by far the most expensive diets in the swine industry, mainly due to the need to reduce Post-Weaning Diarrhea (PWD) and optimize growth performance by including highly digestible feed ingredients with low content of antinutritive factors. It would therefore be economically advantageous, if some of the expensive protein sources that are generally considered necessary in diets for newly weaned piglets could be substituted with soy bean meal (SBM). Unfortunately, SBM contains several antinutritive factors, and $\beta$-mannan is one of them, which also is found in many other common feed ingredients [1], that have received increasing attention in recent years. $\beta$-Mannans are linear polysaccharides with a backbone mainly composed of repeating units of $\beta-1,4$-mannose and $\alpha$-1,6-galactose and/or glucose units attached to the backbone $[2,3]$. They are considered unsuitable for young piglets due to their antinutritive properties, mainly due to stimulation of the innate immune response. The innate immune cells identify pathogens using distinct molecules, called pathogen associated molecular patterns (PAMP), expressed on the pathogen surface [4]. Binding of PAMP to pathogen recognition receptors (PRR), present on innate immune cells, results in the release of innate defense molecules such as reactive oxygen and nitrogen species, bacteriolytic enzymes, antimicrobial peptides and complement proteins [5]. These PAMP include complex polysaccharides such as $\beta$-mannan [4]. Therefore, $\beta$-mannans from feed can create a false signal about the presence of pathogens in the gut, that elicits an unwarranted immune activation [6,7], which is also known as a feed induced immune response (FIIR). The recognition of $\beta$-mannans elicits a futile immune response that causes energy and nutrients to be wasted [3]. Hydrolysis of these $\beta$-mannans by dietary inclusion of an exogenous $\beta$-mannanase enzyme can reduce and potentially eliminate their ability to induce FIIR.

Supplementation of $\beta$-mannanase to low- and high-mannan diets has the potential to improve the performance of growing pigs [8]. Moreover, ingredients with high $\beta$-mannan content like palm kernel meal (PKM) or copra meal may partially replace SBM without reducing pig performance if $\beta$-mannanase is supplemented to the diet $[8,9]$. Some researchers have suggested that the improved pig performance following $\beta$-mannanase supplementation to corn-SBMPKM diets might be due to increased ileal digestibility of different amino acids [10-12]. Others concluded that $\beta$-mannanase improved growth performance in both weanling and growing-finishing pigs on corn-SBM diets [13-15] with minimal effects on nutrient digestibility 
Frédéric Vangroenweghe (2020) Substitution of Expensive Protein Sources by Soybean Meal Supplemented with a $\beta$-Mannanase Enzyme Results in Improved General Clinical Health Score during the Post-Weaning Period

[14]. Innate immune activation is accompanied by down-regulation of anabolic functions [16], which translates into a reduced performance capacity. Understanding energy and nutrient partitioning in immunestressed piglets may provide more insights into the effects of FIIR activation by $\beta$-mannans from feed.

The objective of the current study was to evaluate the effects of $\beta$-mannanase supplementation to nursery diets with reduced content of expensive, high quality proteins on performance of nursery piglets in the presence of a natural $E$. coli PWD infection.

\section{Materials and Methods}

\section{Description of Experimental Farm}

The trial was performed in a post-weaning facility receiving batches of piglets $(n=160)$ from the same sow farm in Flanders (Belgium), operated with a 4-week batch-management system. The post-weaning facility is managed on all-in/all-out basis in all production phases. This management approach improved the health status for several respiratory pathogens [17].

Piglets were weaned at 21 days of age, and immediately transported to a specifically equipped post-weaning facility, where they were raised for 47 days post-weaning (dpw). The post-weaning facility was equipped with 2 compartments, each with 16 pens of 10 piglets with one central inspection aisle. Every pen was equipped with a dry feeder, a separate waterer, and fully slatted plastic floors. Heating was provided by hot water tubes on the ceiling and ventilation was performed through one evacuation ventilator positioned centrally in the compartment. Fresh air entered into the compartment through a system of door ventilation following a passage through a central corridor.

\section{Experimental Design}

\section{Treatment Groups and Feeding Regimen}

Two experimental treatments were used, where T-1 (Control) received the standard diets and T-2 (Enzyme) received the adapted nursery diets. A 2-phase feeding program with two basal mash diets was used: a common commercial diet, and a similar adapted diet with $300 \mathrm{~g} /$ tonne of a heat-tolerant endo-1,4- $\beta$-mannanase (Hemicell HT Dry; Elanco), where expensive protein sources were partially replaced with extruded SBM in phase 1 . The $\beta$-mannanase enzyme was added on top in phase 1 and formulated to provide $63 \mathrm{kcal} / \mathrm{kg} \mathrm{NE}$ in phase 2 . The composition and nutrient content of the diets are given in Tables 1 and 2. The phase 1 diets were offered from days 1-21 and phase 2 from days 22-47.

\section{Study Animals}

Two batches of 160 newly weaned piglets were allocated to treatment by weight and sex. Castrated males and females were penned separately. The same number of castrated male and female piglets were allocated to both treatment groups. All piglets were ear tagged with individual identification numbers.

\section{Data Collection}

Pigs were evaluated daily and any unusual observations were recorded, including but not limited to altered behavior and disease.
Table 1: Composition of the diets.

\begin{tabular}{|l|c|c|c|c|}
\hline & \multicolumn{2}{|c|}{ Phase 1 } & \multicolumn{2}{c|}{ Phase 2 } \\
\hline Composition (\%) & Control & Enzyme & Control & Enzyme \\
\hline Wheat & 32.00 & 32.00 & 33.42 & 26.75 \\
\hline Barley & 19.82 & 18.94 & 25.00 & 25.00 \\
\hline Wheat gluten feed & - & - & 0.00 & 5.00 \\
\hline Danex GGO-F (extruded SBM) & 10.00 & 8.00 & - & - \\
\hline Soya 48 & 7.74 & 9.88 & 18.74 & 17.58 \\
\hline Corn & 7.50 & 7.50 & 10.00 & 10.00 \\
\hline Rice feed meal & - & - & 3.00 & 3.00 \\
\hline Whey powder, sweet & 6.00 & 6.00 & - & - \\
\hline Rape seed meal & - & - & 1.47 & 2.00 \\
\hline Corn, extruded & 5.00 & 5.00 & - & - \\
\hline Potato protein & 2.00 & 1.85 & - & - \\
\hline $\begin{array}{l}\text { Wheat milling byproduct (15,3\% CP; 8,4\% } \\
\text { CF; 21\% starch) }\end{array}$ & - & - & 0.00 & 2.43 \\
\hline Beet pulp & 2.00 & 2.00 & 2.00 & 2.00 \\
\hline Spelt bran & 2.00 & 2.00 & 2.00 & 2.00 \\
\hline Soy oil & 0.39 & 0.91 & 0.34 & 0.00 \\
\hline Fish oil & 0.50 & 0.50 & - & - \\
\hline Fatty acids 30\% linoleic acid & - & - & 0.50 & 0.50 \\
\hline Premix, enzymes, amino acids, acids, salt & 5.05 & 5.12 & 2.97 & 2.91 \\
\hline Monocal & - & - & 0.31 & 0.28 \\
\hline Limestone & - & - & 0.25 & 0.24 \\
\hline Hemicell HT (10\%) & 0.00 & 0.30 & 0.00 & 0.30 \\
\hline
\end{tabular}

Table 2: Calculated nutrient content of the diets.

\begin{tabular}{|l|c|c|c|c|}
\hline & \multicolumn{2}{|c|}{ Phase 1 } & \multicolumn{2}{c|}{ Phase 2 } \\
\hline Nutrient content & Control & Enzyme & Control & Enzyme \\
\hline Crude protein (\%) & 17.74 & 17.69 & 17.50 & 17.50 \\
\hline Crude fat (\%) & 4.82 & 4.97 & 3.50 & 3.58 \\
\hline Crude fibre (\%) & 4.12 & 4.11 & 4.38 & 4.81 \\
\hline Crude ashes (\%) & 4.53 & 4.55 & 4.34 & 4.49 \\
\hline Sugar (\%) & 5.59 & 5.62 & 3.71 & 4.00 \\
\hline Starch (\%) & 38.65 & 38.16 & 42.17 & 39.51 \\
\hline NE content (kcal/kg) & 2450 & 2,450 & 2,400 & 2,337 \\
\hline Lysine, total (\%) & 1.37 & 1.37 & 1.19 & 1.19 \\
\hline Methionine, total (\%) & 0.50 & 0.50 & 0.38 & $0 . .39$ \\
\hline Lysine, digestible (\%) & 1.13 & 1.13 & 0.96 & 0.96 \\
\hline Methionine \& Cysteine, digestible (\%) & 0.66 & 0.66 & 0.56 & 0.56 \\
\hline Methionine, digestible (\%) dv VARK & 0.44 & 0.44 & 0.32 & 0.32 \\
\hline Threonine, digestible (\%) & 0.71 & 0.71 & 0.61 & 0.61 \\
\hline Trypsin, digestible (\%) & 0.23 & 0.23 & 0.23 & 0.23 \\
\hline Isoleucine, digestible (\%) & 0.57 & 0.57 & 0.55 & 0.54 \\
\hline Leucine, digestible (\%) & 1.07 & 1.07 & 1.03 & 1.01 \\
\hline Valine, digestible (\%) & 0.74 & 0.74 & 0.63 & 0.63 \\
\hline Calcium (Ca; \%) & 0.60 & 0.60 & 0.60 & 0.60 \\
\hline Phosphor, total (P; \%) & 0.52 & 0.52 & 0.49 & 0.49 \\
\hline Phosphor, digestible (P; \%) & 0.38 & 0.38 & 0.30 & 0.30 \\
\hline Sodium (Na; \%) & 0.23 & 0.23 & 0.20 & 0.20 \\
\hline Magnesium (Mg; S) & 0.17 & 0.17 & 0.18 & 0.20 \\
\hline Potassium (K: \%) & 0.77 & 0.77 & 0.74 & 0.77 \\
\hline Chlorine (Cl; \%) & 0.36 & 0.36 & 0.28 & 0.28 \\
\hline Na+K-Cl (meq/kg) & 19.65 & 19.79 & 19.90 & 20.72 \\
\hline
\end{tabular}


Frédéric Vangroenweghe (2020) Substitution of Expensive Protein Sources by Soybean Meal Supplemented with a $\beta$-Mannanase Enzyme Results in Improved General Clinical Health Score during the Post-Weaning Period

Normal performance data were collected such as bodyweight on day 1 (trial start), day 21 (end phase 1) and day 49 (end of trial). General clinical score (GCS) and fecal clinical score (FCS) were assessed weekly from day 4 until the end of the trial (day 47) and described by pen. GCS or general pig appearance was scored on a scale from 1-8 with 1 rated as poor and 8 as excellent. FCS or diarrhea scores were assessed for each pen by scoring five droppings per pen based on the criteria shown in Table 3. Feed allocation was recorded daily as feed bags of $25 \mathrm{~kg}$ were added to the feeders, and assumed to equal feed intake. Average daily weight gain (ADWG), feed intake (FI), and feed conversion ratio (FCR) were calculated for each feeding period and overall. No veterinary treatments were needed during the duration of the trial. No adjustments for mortality and culls were performed, since mortality was below $2.0 \%$ and no culls occurred during the trial.

\section{Statistical Analysis}

Feeder was the experimental unit for data collected related to ADWG, FCR FI, FCS and GCS. The data were examined for outliers (defined as results that deviate from the mean by over 3 standard deviations), and none were found. The performance results were analyzed for differences between treatment groups by ANOVA using JMP version 14.0.

\section{Results}

\section{Piglet Weight and Average Daily Weight Gain}

Piglets were weaned at 21 days of age and an average weight of 5.73 $\mathrm{kg}( \pm 0.06)$ and were randomly distributed on two treatment groups. At the end of phase 1 weighing (day 21), T-1 piglets were slightly, but not-significantly $(P>0.05)$ lighter compared to T-2 piglets $(10.02 \pm$ $0.12 \mathrm{~kg} v s .10 .25 \pm 0.13 \mathrm{~kg}$, respectively). The final weight differed by only $100 \mathrm{~g}(23.33 \pm 0.26 \mathrm{~kg} v s .23 .43 \pm 0.29 \mathrm{~kg}$, respectively) and was not significantly different $(P>0.05)$ (Figure 1).

Average daily weight gain in phase 1 was $12 \mathrm{~g} / \mathrm{d}$ lower in T-1 piglets compared to T-2 piglets. In phase 2, T-2 piglets grew a little slower with $7 \mathrm{~g} / \mathrm{d}$ lower ADWG as compared to T-1. Average daily weight gain was not significantly $(P>0.05)$ different between treatments (Figure 2$)$.

\section{Feed Intake and Feed Conversion Rate}

Feed intake in T-1 piglets was $17 \mathrm{~g} / \mathrm{d}$ lower in phase 1 and $3 \mathrm{~g} / \mathrm{d}$ higher in phase 2 as compared to T-2 piglets. However, the differences in FI were not significant $(P<0.05)$ between treatment groups (Figure 3 ).

Feed conversion rate in phase 1 did not differ significantly between treatment groups $(1.32 \pm 0.012$ and $1.33 \pm 0.017$ for T- 1 and T-2 piglets $(P>0.05)$, respectively). In phase $2, \mathrm{FCR}$ in T-2 piglets $(1.67 \pm 0.012)$ was slightly, but not significantly higher $(P>0.05)$ as compared to T-1 piglets $(1.65 \pm 0.017)$ (Figure 4$)$.

Table 3: Comprehensive description of the pen fecal clinical score with its interpretation and clinical aspect of the fecal clinical score (adapted from $[18,19]$ ).

\begin{tabular}{|l|l|l|}
\hline Score & Interpretation & Clinical aspect \\
\hline 0 & Normal & Normal fecal consistency \\
\hline 1 & Pasty to mild & Soft pasty consistency with more particles than fluid \\
\hline 2 & Moderate to severe & More fluid than particles \\
\hline
\end{tabular}

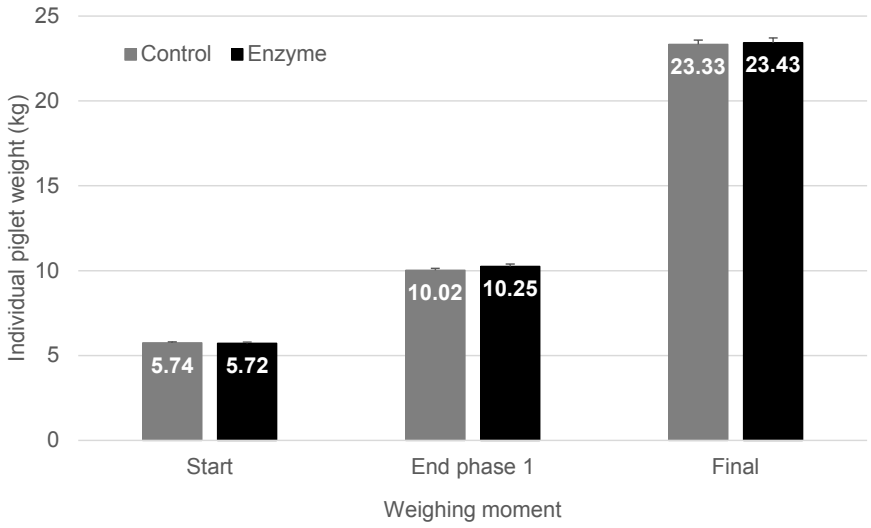

Figure 1: Individual piglet weight (kg; mean \pm SEM) at weaning (Start), intermediate weighing (End phase 1; $21 \mathrm{dpw}$ ), and end of the trial (Final; $47 \mathrm{dpw})$. No significant differences $(P>0.05)$ between groups could be observed.

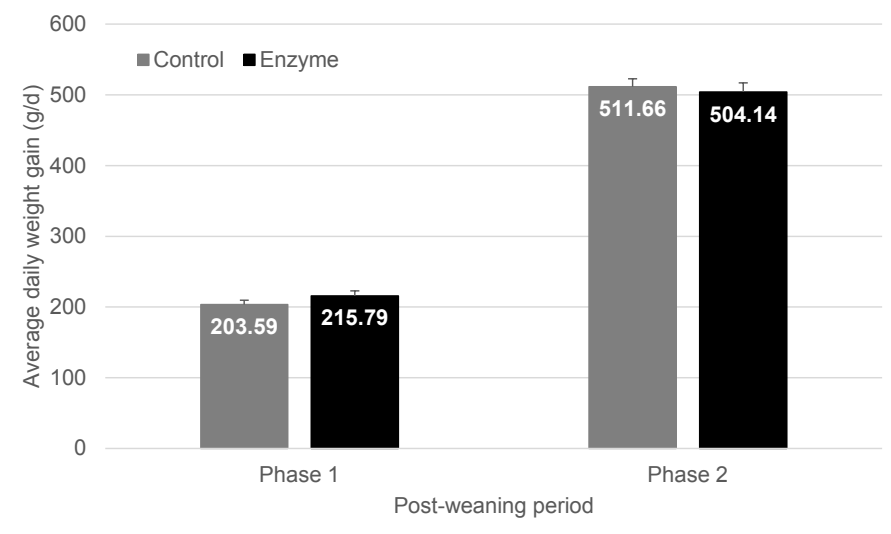

Figure 2: Average daily weight gain $(\mathrm{g} / \mathrm{d}$; mean \pm SEM) in phase $1(0-21 \mathrm{dpw})$ and phase $2(22-47 \mathrm{dpw})$. No significant differences $(P>0.05)$ between groups could be observed.

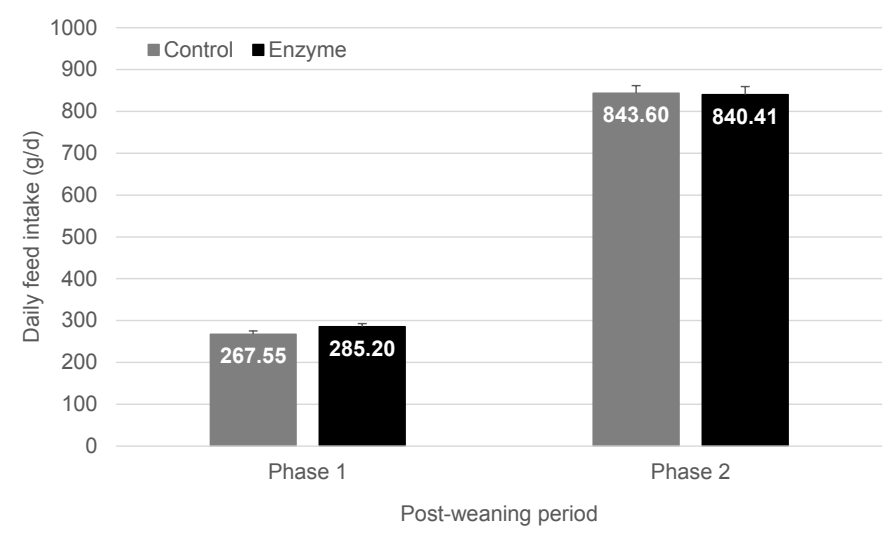

Figure 3: Piglet feed intake per phase $(\mathrm{kg} /$ piglet; mean \pm SEM) in phase $1(0-21 \mathrm{dpw})$, and phase $2(22-47 \mathrm{dpw})$. No significant differences $(P>0.05)$ between groups could be observed.

\section{Pen fecal Clinical Score and General Clinical Score}

Pen FCS was collected weekly for each individual pen from 4 to 47 dpw. No differences were found in FCS between treatments, neither in weekly average pen FCS, nor in pen FCS, expressed as area under the curve (AUC) $(P>0.05)$.

Pen GCS was collected weekly from 4 to $47 \mathrm{dpw}$. Weekly average pen GCS (mean \pm SEM) is given in Figure 5. Pen GCS, expressed as AUC, was significantly better $(P \leq 0.05)$ in the Enzyme-treated group as compared to the Control group. 

Improved General Clinical Health Score during the Post-Weaning Period

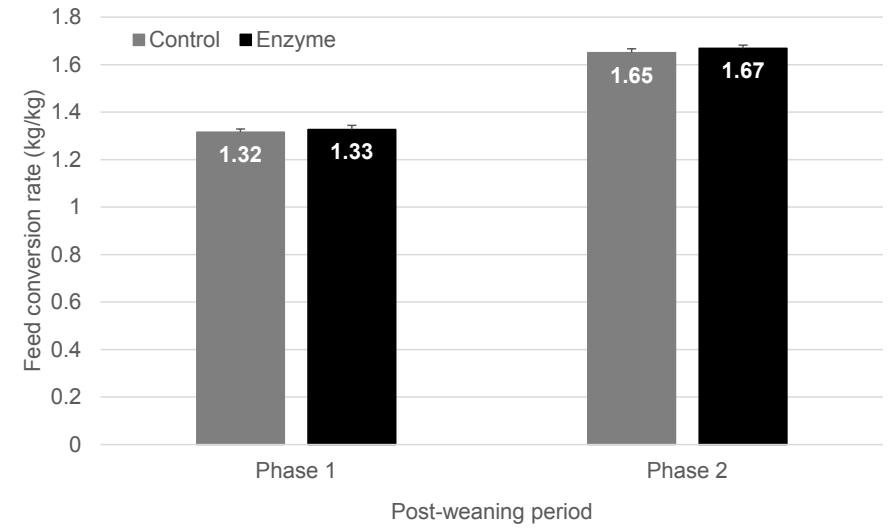

Figure 4: Feed conversion ratio $(\mathrm{kg}$ feed/kg weight gain; mean \pm SEM) in phase $1(0-21$ $\mathrm{dpw})$ and phase $2(22-47 \mathrm{dpw})$. No significant differences $(P>0.05)$ between groups could be observed.

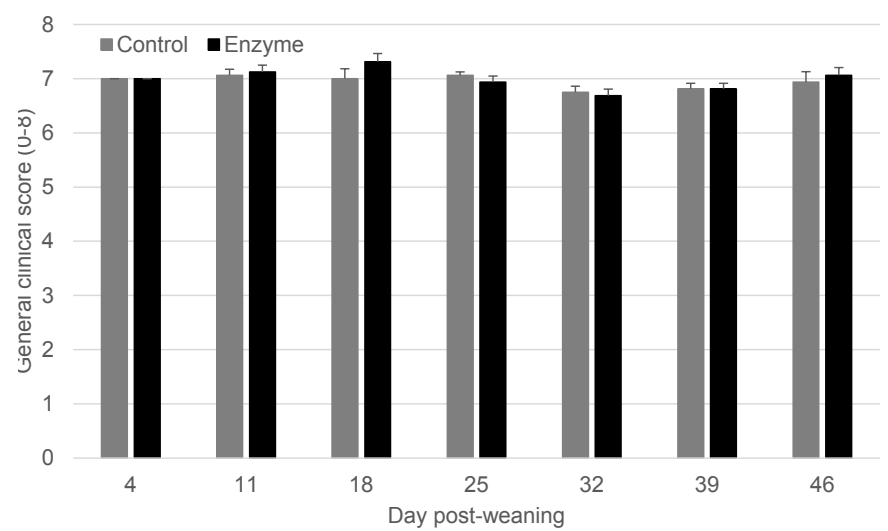

Figure 5: Average general clinical score (mean \pm SEM) from 4 to 46 dpw. Piglets in each pen were scored weekly on a scale from 1 to $8(1=$ poor, $8=$ perfect $)$ during the trial. The overall general clinical score was significant better $(P \leq 0.05)$ in the Enzyme-treated piglets as compared to the Control piglets.

\section{Mortality and Antimicrobial Treatment}

No mortality and no culls were recorded during the trial. Antimicrobial treatment was not necessary during the duration of the trial.

\section{Discussion}

In the current study, we substituted a part of the most expensive protein sources (patato protein concentrate and Danex GGO-F) with dehulled SBM (soya 48) in phase 1, and wheat was partially substituted with wheat gluten feed and wheat milling byproduct in phase 2 . The basal diets were estimated to have similar and relatively high soluble $\beta$-mannan content of $0.30 \%$ in phase 1 and $0.33 \%$ in phase 2 , a known antinutritive factor [1], which may stimulate an innate immune response through their resemblance with PAMPs [4]. This activation has been called FIIR and leads to an unnecessary immune activation, which causes energy and nutrients to be wasted [3]. The current results from phase 1 revealed no differences between treatments in piglet weight, FI, ADWG or FCR. The results confirmed that the adapted diet with an exogenous $\beta$-mannanase and lower content of expensive protein sources performed equal to the standard diet used in phase 1. These results are in accordance with other recent studies [8].

In phase 2, the Enzyme-treated diet was formulated to contain 63 $\mathrm{kcal} / \mathrm{kg} \mathrm{NE}$ less than the control diet, which reduced the inclusion of soya oil from $0.34 \%$ to $0 \%$. Again, in phase 2 only minor numerical performance differences were observed between treatments. The overall result therefore confirmed that the addition of $\beta$-mannanase to diets formulated with reduced content of expensive protein sources in phase 1 and about 3\% lower dietary net energy content in phase 2 allowed performance to be maintained. Others concluded that $\beta$-mannanase improved growth performance in both weanling and growing-finishing pigs on corn-SBM diets [13-15]. The energy sparing effect observed in phase 2 has also been observed by others. Supplementation of $\beta$-mannanase to common nursery diets resulted in similar performance as comparable diets with $2 \%$ added soya oil [14]. In our study, a further substitution of potato protein with a cheaper protein source, would likely have been possible. Nevertheless, from a commercial perspective, equal piglet performance on diets with $63 \mathrm{kcal} / \mathrm{kg}$ lower net energy content in phase 2 is an attractive option for the animal feed industry [20].

In conclusion, the current study suggests that the use of an exogenous heat-tolerant $\beta$-mannanase allowed reduced levels of expensive protein sources to be used in the first diet fed post-weaning, and $63 \mathrm{kcal} / \mathrm{kg}$ lower net energy content to be used in the second diet without loss of performance or adverse effects on intestinal health. In fact, the general clinical score was significantly improved on the diets with $\beta$-mannanase.

\section{Acknowledgement}

The authors greatly acknowledge the technical staff of the experimental facility (Quartes-Verzele, Nevele) for their assistance in randomization, weighing and data collection.

\section{Abbreviations}

AUC: Area Under the Curve

dpw: Days Post-Weaning

FCS: Fecal Clinical Score

FIIR: Feed Induced Immune Response

GCS: General Clinical Score

NSP: Non-Starch Polysaccharide

PAMP: Pathogen Associated Molecular Pattern

PRR: Pathogen Recognition Receptor

PWD: Post-Weaning Diarrhea

SBM: Soybean Meal

\section{References}

1. Ferrel J, Anderson DM, Hsiao HY (2014) Content of Soluble Non-Starch Polysaccharides $\beta$-Mannan and Xylan in Legume Meals, Non-Legume Meals, and Cereal Grains or Cereal Grain by-products. Journal Animal Science 92: 328.

2. Jackson ME, Geronian K, Knox A, McNab J, McCartney E (2004) A dose-response study with the feed enzyme $\beta$-mannanase in broilers provided with corn-soybean meal based diets in the absence of antibiotic growth promoters. Poult Sci 83: 1992-1996. [crossref]

3. Hsiao HY, Anderson DM, Dale NM (2006) Levels of $\beta$-mannan in soybean meal. Poult Sci 85: 1430-1432. [crossref]

4. Forsberg NE, Wang Y (2006) Nutrition and immunity in dairy cattle: implications to hemorrhagic bowel syndrome. Proc. Mid-South Rum Nutr Conf 11-20. 
Frédéric Vangroenweghe (2020) Substitution of Expensive Protein Sources by Soybean Meal Supplemented with a $\beta$-Mannanase Enzyme Results in Improved General Clinical Health Score during the Post-Weaning Period

5. Sukhithasri V, Nisha N, Biswas L, Kumar VA, Biswas R (2013) Innate immune recognition of microbial cell wall components and microbial strategies to evade such recognitions. Microb Res 168: 396-406. [crossref]

6. Zhang L, Tizard IR (1996) Activation of a mouse macrophage cell line by acemannan: the major carbohydrate fraction from Aloe vera gel. Immunopharmacology 35: 119128. [crossref]

7. Duncan CJG, Pugh N, Pasco DS, Ross SA (2002) Isolation of a galactomannan that enhances macrophage activation from the edible fungus Morchella esculenta. J Agric Food Chem 50: 5683-5685. [crossref]

8. Kim JS, Ingale SL, Hosseindoust AR, Lee SH, Lee JH et al. (2017a) Effects of mannan level and $\beta$-mannanase supplementation on growth performance, apparent total tract digestibility and blood metabolites of growing pigs. Animal 11: 202-208.

9. Kim HJ, Nam SO, Jeong JH, Fang LH, Yoo HB, et al. (2017b) Various levels of copra meal supplementation with $\beta$-mannanase on growth performance, blood profile, nutrient digestibility, pork quality and economical analysis in growing-finishing pigs. J Anim Sci Technol 59: 19-28.

10. Mok CH, Lee JH, Kim BG (2013) Effects of exogenous phytase and $\beta$-mannanase on ileal and total tract digestibility of energy and nutrient in palm kernel expellercontaining diets fed to growing pigs. Anim Feed Sci Technol 186: 209-213.

11. Upadhaya SD, Park JW, Lee JH, Kim IH (2016) Ileal digestibility of nutrients and amino acids in low quality soybean meal sources treated with $\beta$-mannanase for growing pigs. Animal 10: 1148-1154. [crossref]

12. Jeon SM, Hosseindoust A, Choi YH, Kim MJ, Kim KY et al. (2019) Comparative standardized ileal amino acid digestibility and metabolizable energy contents of main feed ingredients for growing pigs when adding $\beta$-mannanase. Anim Nutr 5: 359-365.
13. Lv JN, Chen YQ, Guo XJ, Piao XS, Cao YH et al. (2013) Effects of supplementation of $\beta$-mannanase in corn-soybean meal diets on performance and nutrient digestibility in growing pigs. Asian-Aust J Anim Sci 26: 579-587.

14. Pettey LA, Carter SD, Senne BW, Shriver JA (2002) Effects of beta-mannanase addition to corn-soybean meal diets on growth performance, carcass traits, and nutrient digestibility of weanling and growing-finishing pigs. J Anim Sci 80: 10121019. [crossref]

15. Jo JK, Ingale SL, Kim JS, Kim YW, Kim KH, et al. (2012) Effects of exogenous enzyme supplementation to corn- and soybean meal-based or complex diets on growth performance, nutrient digestibility, and blood metabolites in growing pigs. J Anim Sci 90: 3041-3048. [crossref]

16. Humphrey BD, Klasing KC. 2005. The acute phase response alters cationic amino acid transporter expression in growing chickens (Gallus gallus domesticus). Comp. Biochem. Physiol. A Mol. Integr. Physiol. 142: 485-494.

17. Vangroenweghe F, Suls L, Van Driessche E, Maes D, De Graef E (2012) Health advantages of transition to batch management system in farrow-to-finish pig herds. Vet Med 57: 83-91.

18. Vangroenweghe F, Thas O. 2020a. Improved piglet performance and reduced antibiotic use following oral vaccination with a live avirulent Escherichia coli F4 vaccine against post-weaning diarrhea. J Clin Res Med 3: 1-8.

19. Vangroenweghe F, Thas O. 2020b. Application of high energy and protein diets in combination with a live avirulent Escherichia coli F4 vaccine against post-weaning diarrhea. Vacc Res 7: 1-9.

20. Cromwell GL, Soybean Meal InfoCenter, Arkeny IA (2017) Soybean meal: an exceptional protein source.

\section{Citation:}

Frédéric Vangroenweghe and Poulsen Karl (2020) Substitution of Expensive Protein Sources by Soybean Meal Supplemented with a $\beta$-Mannanase Enzyme Results in Improved General Clinical Health Score during the Post-Weaning Period. Integr I Vet Biosci Volume 4(2): 1-5. 